\title{
Current State of Building Information Modelling in the Nigerian Construction Industry
}

\section{Oludolapo Ibrahim Olanrewaju*, Sunday Ajiboye Babarinde, Comfort Salihu}

Dollahills Research Lab, Dollasoft Technologies, Lagos, Nigeria

*Corresponding author: oludolapoolanrewaju2012@gmail.com

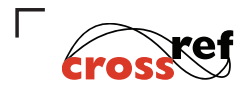

http://dx.doi.org/10.5755/j01.sace.27.2.25142
Building Information Modelling (BIM) has been applied to various aspects of construction processes in developed countries but Nigeria is yet to realize the full potentials of BIM. It has greater relevance for the commercial and public subsectors as it enhances construction productivity. This study examines the current state of BIM in the Nigerian construction industry. The study adopted a quantitative research approach by eliciting primary data through a questionnaire which was administered to 150 respondents, of which 90 were returned and considered valid for further analysis. The data were analyzed using mean item score and Pearson correlation. It was revealed that BIM awareness level is only high at the design stage of a building life cycle while it is extremely low at the construction and facility management stages. Also, the commonly used BIM compliant software packages in the Nigerian construction industry were identified to be: Autodesk Quantity Takeoff, Revit Architecture, and SketchUp. However, the study recommends stakeholders education, openness to new technologies, investment in BIM research, and policy development.

Keywords: Building Information Modelling, BIM, Construction Industry, Built Environment Professionals, Nigeria.

Several studies have shown that developing countries like Nigeria that need infrastructures are top markets for Architecture, Engineering, and Construction (AEC) industry. Owing to inadequate resources and economic downturn, policies regarding sustainable development and construction have gained remarkable attention. The adoption of new technologies and their effective implementation have become the only way for closing the gap with developed countries (Akdag and Maqsood, 2019).

The construction industry is envisioned as the major driver of the economy with $5 \%$ increase in GDP growth, other sectors like health, education, transportation and the likes depend heavily on the construction industry (Olanrewaju et al., 2018). The industry is divided into three sectors which include; informal sector, commercial sector, and public sector. Building Information Modeling (BIM) has greater relevance for commercial and public subsectors (Alufohai, 2012). The introduction of technology to activities in the construction industry has proven beyond every reasonable doubt that the future of the industry is hinged on its adoption of technological innovations in its
JSACE $2 / 27$

Current State of Building Information Modelling in the Nigerian Construction Industry

Received 2020/01/22

Accepted after revision 2020/06/19

\section{Introduction}

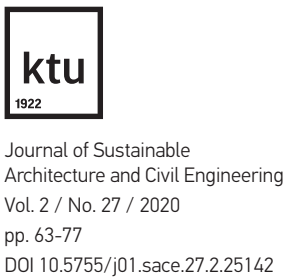


activities (Maurico, 2001). BIM has also been highlighted by the AEC industry as a powerful design and management tool that has significant advantages over the building life cycle, design and management (Yan and Damian, 2008).

BIM acronym stands for Building Information Model, Building Information Modelling and Building Information Management (Babarinde, 2017). According to Royal Institution of Chartered Surveyors [RICS] (2014), the concept of BIM has no accepted definition due to its ever-evolving nature where new areas and frontiers are creeping into the boundaries of what it could be defined as. Various definition of BIM exists each of them characterized by certain key point such as in referring to BIM as a "product", a "process", "technology", an "innovation" or a "strategy" (Babarinde, 2017). Penttilä (2006) stated that "BIM involves the process, policies and technology interactions to produce a method for managing importance of building design and project data in digital format or virtual through the building life cycle". Also, it is believed that BIM connects all the professionals in the construction industry, this allows for information sharing within the project context and hence promotes collaborative work among professionals such as architects, contractors, surveyors, designers, and owners on a common information system. Furthermore, BIM was described as a digital representation of physical and functional characteristics of a facility creating a shared knowledge resource for information about it and thus forming a reliable basis for decisions during its life cycle, from conception to demolition (Eastman et al., 2011; Snook 2011; Suranga and Weddikkara, 2012).

Many researchers have explored the concept of BIM as regards developing countries. For instance, Akdag and Maqsood (2019) highlighted the potentials of BIM for developing countries using Pakistan as the study area. Similarly, Olawumi and Chan (2018) explored BIM implementation and practices in developed economies by developing a benchmarking model that will enhance BIM adoption and implementation in developing countries. Furthermore, Anifowose et al. (2018) assessed the adoption level of BIM by the selected Nigerian professionals in the built environment and revealed that less than $50 \%$ of the professionals were familiar with BIM concept. Few studies on BIM and lack of requisite knowledge were revealed as the major deterrent to BIM adoption. Gamil and Rahman (2019) investigated the awareness of Yemen construction practitioners on the adoption of BIM and identification of the dominant challenges of implementing BIM in the life cycle of a construction project.

Even though BIM provides solutions to the numerous problems inherent in the construction industry (Eastman et al., 2011; Aryani et al., 2013; Kushwaha, 2016), it is still confronted with several challenges in the Nigerian construction industry. In addition, Usman (2015) stated that the individuals' readiness presents a greater setback to BIM than the process, management, and technology involved in its adoption. BIM has received considerable attention in developing countries over the last decade. Hence this research seeks to examine the current state of BIM in the Nigerian construction industry.

BIM Use and Construction Professionals
$\mathrm{BIM}$ as a tool for various stakeholders of the construction industry, its usage varies from the inception of the construction to the final stage of the building whole lifecycle. Various professionals like the architects, builders, estate surveyors, structural engineers, services engineer, and facility managers whose duties at times may be superimposed into various professions. The following are BIM uses at different stages of a building life cycle:

\section{Design Stage}

Design is usually carried out by the design team which usually comprises the Architects, Structural engineers, Services engineer and Builders depending on the project complexity. The design stage of the building occupies a vital position in the life of the building which is the stage in which all the decisions pertaining to what the building will be and consists of is made. The major uses of BIM in the design stage lie in construction planning, visualization, cost estimation, 3D coordination, constructability analysis, prefabrication, sequencing and incorporating sustainability issues in the 
design (Schueter and Thessling, 2008; Foster, 2011). The design team is then required to produce the requirement of the client in an understandable format to all the expected project team, especially the client who is to be the financier of the project. The design team must of a necessity ensure the buildability, aesthetics, structural ability, and functionality of the building (Babarinde, 2017).

\section{Construction / Building Stage}

At this stage, the design has been completed and the actual construction of the facility is in progress, issues regarding building, financing and management of the facility have been finalized. The contractors have been selected and the design team of the client assumes an oversight and supervisory role to the construction stage, the contractor(s) is provided with the design details and the 3D model of the building in which he offers definite and concise addition as regards his expert knowledge on the constructability and variety of issues likely to be experienced in the course of the building use (Babarinde, 2017). Authors like Eastman et al. (2011) and Azhar et al. (2012), have highlighted construction monitoring and modelling, and fabrication as the anchor uses of BIM tools in the construction stage of a building. The BIM model enables the contractor's team (Architect, Quantity Surveyors, Engineers, Masons and other professionals as their service may be required) to visualize a progressive stage by stage construction process simulation, this eases the work of all parties involved by enabling the various professionals to settle constructability, durability, cost efficiency and suitability issues in the construction process.

\section{Operation / Facility Management Stage}

This stage of the building process has been discovered by various researchers to suffer a high level of neglect which has resulted in gross infrastructural decay in the nation. This problem can be eased by the use of BIM-compliant software for managing the building incorporating operation and management decisions into the design of the facilities in which the function of each space has been decided, the maintenance has been planned and scheduled, the functionality of the components inherent in the facilities can carry the expected population without deficiencies. Moreover, as stated by Patacas et al. (2014) that the future of effective and efficient facility management rests on the hoar of how readily the industry has adopted the BIM for the management of buildings especially high-rise building emerging in the state, which is known to present to facility managers great challenges because of the numerous aspects and component inherent in such structures. Thus, this function of the facility managers is further divided into various subtasks in which BIM can enhance the productivity levels of these tasks include Maintenance scheduling using the Construction Model. Building System Analysis, this is done to determine the building condition, also the asset management function can be carried out using BIM with the spaces adequately allotted to each use with available visual simulation tools available on BIM platform, more importantly, the record model is done incorporating changes made to the building use and spaces the post-construction phase (Jordani, 2010; Reddy, 2012). The task of operation and management is solely the work of the Facility managers which are sometimes carried out by other professionals like Quantity Surveyors and Estate Surveyors due to the lack of proliferation and adequacy of such well trained and certified Facility managers (Jordani, 2010). BIM will enable them to carry out well-planned maintenance which is strictly adhered to, this is a new way of managing building which BIM is championing its course (Babarinde, 2017).

Building Information Modelling as explained earlier has three basic components which include the software used for carrying out modelling activities by the professionals in the construction industry as discussed above. Table 1 gives a breakdown analysis of the various software including details of the Software, Its BIM-related Use, Professionals commonly involved in its use, and BIM-related services it offers to the professionals.

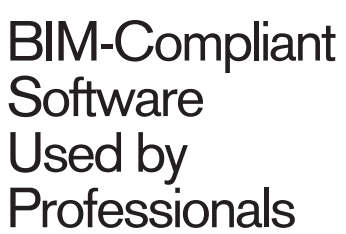




\begin{tabular}{|c|c|c|c|c|c|}
\hline \multirow{15}{*}{$\begin{array}{r}\text { BIM Software and } \\
\text { Tools Analysis }\end{array}$} & $\mathrm{S} / \mathrm{N}$ & Software & Use & Professionals & Services Available \\
\hline & 1. & $\begin{array}{l}\text { Tekla } \\
\text { Structures }\end{array}$ & $\begin{array}{l}\text { Steel and Concrete Detail- } \\
\text { ing, structural models }\end{array}$ & $\begin{array}{l}\text { Structural, Steel and Civil } \\
\text { Engineers }\end{array}$ & $\begin{array}{l}\text { Structural Designer, } \\
\text { Tedds, BIMSight }\end{array}$ \\
\hline & 2. & Archicad & Architectural BIM CAD & Architects & $\begin{array}{l}\text { Parametric Modelling } \\
\text { and Design, Data Inter- } \\
\text { change, Remote Access } \\
\text { and Collaboration }\end{array}$ \\
\hline & 3. & ArchiFM & $\begin{array}{l}\text { Asset Planning, Mainte- } \\
\text { nance, Reporting Services }\end{array}$ & $\begin{array}{l}\text { Facility Managers, Estate } \\
\text { Surveyors }\end{array}$ & $\begin{array}{l}\text { BIM Computer Aided } \\
\text { Facility Management } \\
\text { Software }\end{array}$ \\
\hline & 4. & $\begin{array}{l}\text { Green } \\
\text { Building } \\
\text { Studio }\end{array}$ & $\begin{array}{l}\text { Analysis of Green Building } \\
\text { requirement, Energy Anal- } \\
\text { ysis, Interoperability }\end{array}$ & $\begin{array}{l}\text { Green Building Experts, } \\
\text { Designers, Contractors } \\
\text { and Planners }\end{array}$ & $\begin{array}{l}\text { BIM-Green Building } \\
\text { Standards Integration } \\
\text { Module. }\end{array}$ \\
\hline & 5. & Masterbill & $\begin{array}{l}\text { Integrated CAD and BIM } \\
\text { enabled measurement } \\
\text { Module }\end{array}$ & $\begin{array}{l}\text { Quantity Surveyors, Es- } \\
\text { tate Surveyors, Project } \\
\text { Schedulers }\end{array}$ & $\begin{array}{l}\text { BIM Enabled estimating } \\
\text { and Scheduling ( } 4 D \\
\text { BIM). }\end{array}$ \\
\hline & 6. & $\begin{array}{c}\text { Revit } \\
\text { Architecture }\end{array}$ & $\begin{array}{l}\text { Architectural Designs, } \\
\text { Structural and MEP } \\
\text { modelling }\end{array}$ & $\begin{array}{l}\text { Architects, Services and } \\
\text { Civil Engineers }\end{array}$ & $\begin{array}{l}\text { 4D BIM modelling and } \\
\text { Parametric Design }\end{array}$ \\
\hline & 7. & Skecthup & $\begin{array}{l}\text { Architectural and Mechan- } \\
\text { ical Design and Models, } \\
\text { Interior design, }\end{array}$ & $\begin{array}{l}\text { Architects, Mechanical } \\
\text { and Interior Designers. }\end{array}$ & 3D modelling \\
\hline & 8. & PowerCivil & $\begin{array}{l}\text { Integrated site, building and } \\
\text { aerial planning }\end{array}$ & Design Team & Site Development \\
\hline & 9. & $\begin{array}{l}\text { Digital } \\
\text { Project }\end{array}$ & $\begin{array}{l}\text { Information Sharing and } \\
\text { Interoperability of various } \\
\text { CAD softwares. }\end{array}$ & $\begin{array}{l}\text { Architects, Modelers, } \\
\text { Schedulers }\end{array}$ & $\begin{array}{l}\text { Architectural computer } \\
\text { aided design }\end{array}$ \\
\hline & 10. & $\begin{array}{l}\text { Navisworks } \\
\text { Manage }\end{array}$ & $\begin{array}{l}\text { Complement 3D Design } \\
\text { Packages, 4D Time simu- } \\
\text { lation }\end{array}$ & $\begin{array}{l}\text { Architects, Quantity Sur- } \\
\text { veyors, Scheduler, Project } \\
\text { Managers. }\end{array}$ & $\begin{array}{l}\text { Roamer, Publisher, Clash } \\
\text { Detective, Autodesk } \\
\text { Renderer, Quantification, } \\
\text { Timeliner, Animator, } \\
\text { Scripter }\end{array}$ \\
\hline & 11. & $\begin{array}{l}\text { Autodesk } \\
\text { Quantity } \\
\text { Takeoff }\end{array}$ & Quantity Take-offs & $\begin{array}{l}\text { Quantity Surveyors, } \\
\text { Scheduler }\end{array}$ & $\begin{array}{l}\text { 3D and CAD enabled } \\
\text { quantity taking off }\end{array}$ \\
\hline & 12. & $\begin{array}{c}\text { VICO } \\
\text { Software }\end{array}$ & $\begin{array}{l}\text { Virtual Construction, } \\
\text { Quantity Take-offs, Project } \\
\text { Scheduling, Cost Estima- } \\
\text { tion, Production Control. }\end{array}$ & $\begin{array}{l}\text { Contractors, Quantity } \\
\text { Surveyors, Scheduler, }\end{array}$ & $\begin{array}{l}\text { 5D BIM Virtual } \\
\text { Construction }\end{array}$ \\
\hline & 13. & $\begin{array}{l}\text { Bentley BIM } \\
\text { Suite }\end{array}$ & $\begin{array}{l}\text { Architectural Designs, } \\
\text { Structural and MEP } \\
\text { modelling, }\end{array}$ & $\begin{array}{l}\text { Architects, Services and } \\
\text { Civil Engineers }\end{array}$ & $\begin{array}{l}\text { Architectural, engineer- } \\
\text { ing and Construction, 3D } \\
\text { Modelling }\end{array}$ \\
\hline & 14. & QS CAD & Quantity Take-offs & Quantity Surveyors & $\begin{array}{l}\text { 3D and CAD enabled } \\
\text { quantity taking off }\end{array}$ \\
\hline
\end{tabular}

Source: Ibrahim and Abdullahi (2016); Babarinde (2017). 
The adoption of BIM as a way of representing building information in $3 \mathrm{D}$ and other obtainable dimensions has ushered the construction industry into a new digital construction renaissance, where projects are being built twice, once in the computer and then once flawlessly on-site (Building Information Modelling Guide, 2013). All over the world, BIM is significantly modifying the way that the construction industry creates and cares for its assets; this is because, it allows organizations to identify and resolve issues before they happen, optimize outcomes and reduce process waste, especially rework. BIM has a potential to be used at all stages of the project life-cycle from being used by the owner, by the design team, by the contractor and by the facility managers (Grilo and Jardim-Goncalves, 2010). In fact, BIM is very essential at all stages of the project lifecycle: from being used by the client to understand and express the project's requirements, to the design team from the conceptual design to the full development of the project, to the contractor to manage the project from site clearing to the commissioning and by the facility manager from operation to decommissioning phases. The future of BIM will lead to virtual project designs and construction approach, with a project being completely simulated before being undertaken for real (Froese, 2010).

Adoption of Building Information Modelling as a practice and culture in different countries varies as a result of their perception of new technological innovations and the necessary framework for adopting the innovation. The only project in which BIM is implemented fully i.e from conception to construction stage in Nigeria is the Eko-Atlantic City project which commenced in 2010 and still ongoing. The project is aimed at restoring land lost to coastal erosion over the last century (Adelekan, 2012). It is a public-private partnership-based type of project between South Energy $X$ and Lagos Government. It uses an information-sharing platform referred to as Eko-Atlantic Mobile Application (EAMA) and Augmented Reality (AR). The EAMA is an easy to use application which is regularly updating project presentation, featuring an enhanced virtual tour; this enables easy navigation for the users across the construction works by moving their mobile devices around (Olugboyega, 2016).

Various countries of the world are striving to enshrine BIM into construction activities, with the United Kingdom being at the forefront of this, they necessitated and mandated it that all public projects should be carried out using the BIM thus showing their national disposition to the bringing BIM as the model for all projects (Babarinde, 2017). As stated by Jensen and Johannesson (2014), BIM use is observed to be very limited and recommendations were made for cooperation with governmental authorities towards formulating standard and guidelines related to BIM, these were observed to be obtainable in Denmark and Iceland. Wong et al. (2008) positioned the North America and Scandinavian regions of the world as the construction industry leaders in BIM development and implementation with the adoption by project team professionals soaring from 17\% in 2007 to $71 \%$ in 2012 putting them in the mainstream of BIM usage (McGraw Hill Construction, 2013). This dramatic change was catalyzed by the establishment of a national 3D-4D- BIM program through its Public Buildings services (PBS) office.

Similarly, in the United States (US) significant increases were recorded following the release of two major reports by National Institute of Standards and Technology (NIST) that measured the cost implications of interoperability issues witnessed in the US construction industry. United Kingdom (UK) is also an emerging world leader in the implementation of BIM, with the country's Building and Construction Authority championing its cause by mandating its use on public sector projects by 2015 (Granholm, 2011). Singapore has adopted the Industry Foundation Classes (IFC) as a basis of standard for BIM implementation in their country, hence localizing the standards to design standards in their country (BuildingSmart, 2012).

\section{Adoption of Building Information Modelling}




\section{Eko Atlantic City and BIM Adoption}

Fig. 1

Corporate Tower

Fig. 2

Azuri Peninsula

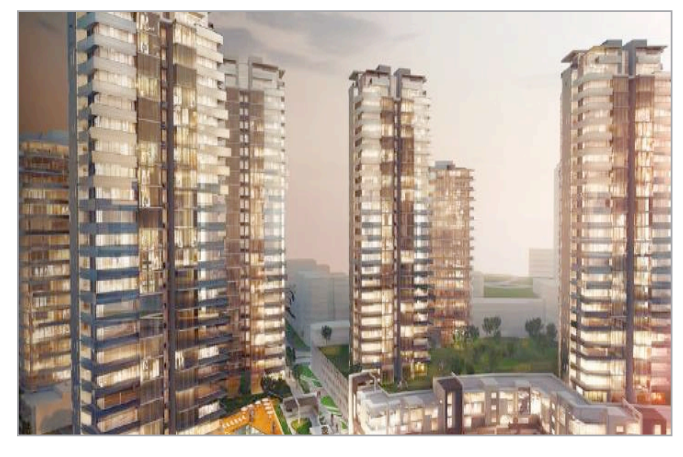

Sources: Eko Brochure (2013); South Energy (2013); Olugboyega (2016).

Fig. 3

Marina Residences

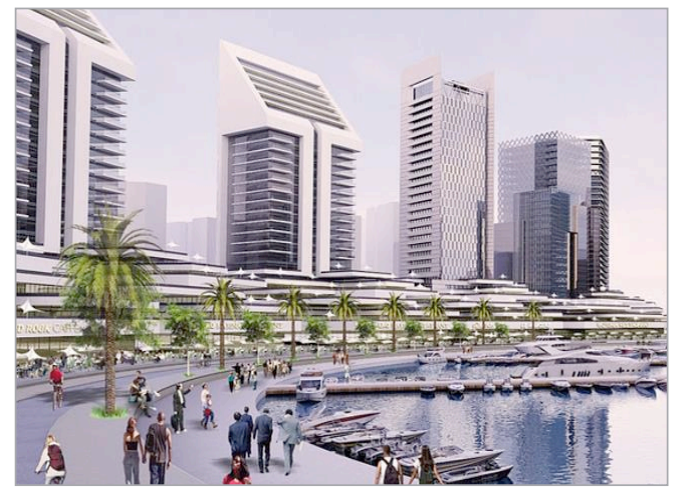

Sources: Eko Brochure (2013); South Energy (2013); Olugboyega (2016).

Fig. 4

Southern Boulevard

Sources: Eko Brochure (2013); South Energy (2013); Olugboyega (2016).
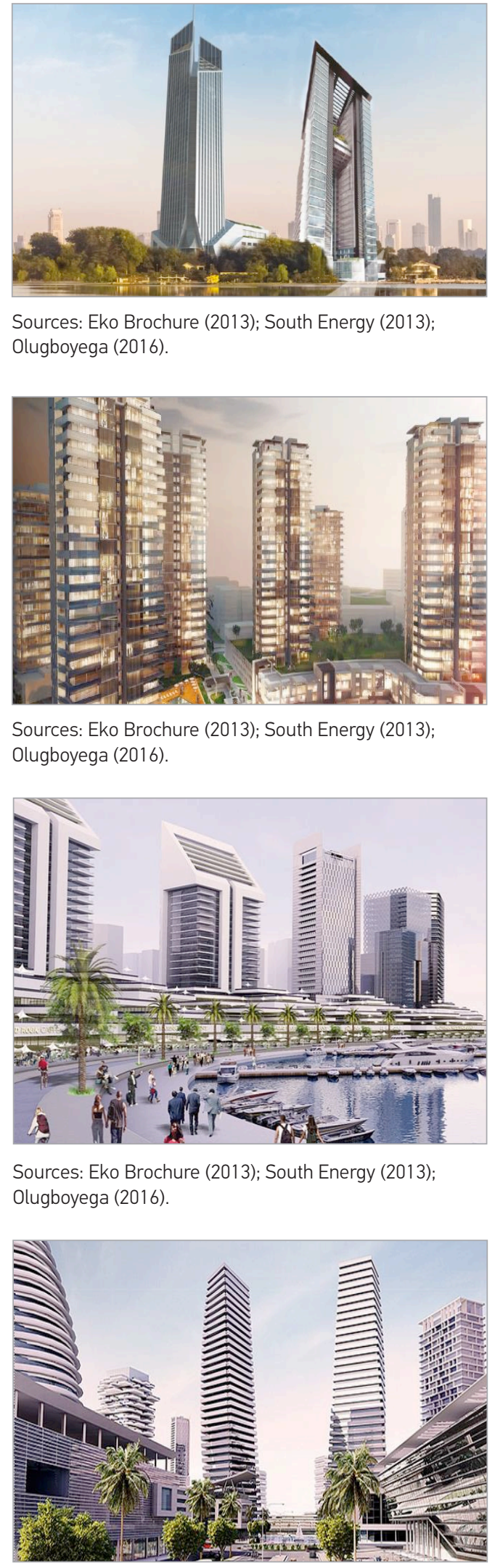

Sources: Eko Brochure (2013); South Energy (2013); Olugboyega (2016).
The history of Eko Atlantic City (EAC) can be traced back to 2003 when Lagos State Government was in search of the best way to solve coastal erosion problems at the Bar Beach off Victoria Island. Between 2003 and 2005, efforts were channelled towards investigating the project feasibility in solving coastal erosion problems. This gave birth to a new city with the sole purpose of protecting shorelines and providing more housing unit (Eko Atlantic, 2016). EAC is a unique city intended to originate from the Atlantic Ocean and is being created to revamp the shorelines of Victoria Island that have been destroyed as a result of coastal erosion. The construction of the city was executed under a public-private partnership between South Energy $X$ Nigeria Limited (SENL) and Lagos State Government. The city is aimed at making Nigeria one of the attractive tourist destination in Africa which will foster economic development (Channels Television, 2010; Ajibade, 2017). In terms of power administration, the city is categorized as its metropolis and will operate on its administration. It will likewise be a seaward financial zone and permit free movement of capital by speculators (Olugboyega, 2016).

The city is specially designed for a wide range of activities including financial, residential, tourists' accommodation, commercial and leisure activities. Upon completion of the project, it is expected to accommodate 250,000 inhabitants and 150,000 commuters. In addition, it is anticipated to have 10 districts which include; Business Districts, Harbor Lights, Marina Districts, Downtown, Eko Island, Avenues, Four Bridges, Eko Drive, East Side Marina and Ocean Front. The design of the city is exceptional as it encompasses independent power supply and water treatment, advanced telecommunications, low carbon footprint, no on-street parking, international school and hospital which were all included in EAC BIM model (South Energy, 2013; Channels Television, 2014; Eko Atlantic, 2016). Oyedeji (2014) added that most buildings in the EAC project were high-rise buildings with setbacks to minimize the effect of shadows on infrastructures. Some of these buildings are named as follows; Eko Corporate Tower, Eko Boulevard, Le Reve Tower, Afren Tower, Eko 
Pearl Towers (Champagne Pearl, White Pearl, Black Pearl, Indigo Pearl, and Acqua Pearl), Azuri Peninsula, Arep Towers, International School, Atlantic Business and Residence, Eko Mall, Eko Energy Estate, 3-Marinas, and Eko Atlantic Medical centre (cf. Olugboyega, 2016). In terms of value, Meseko (2014) revealed the cost of waterfront and inner-city plots to be $\$ 2,000$ / sqm and $\$ 1,000 /$ sqm respectively while the estimated project cost stood at $\$ 6$ billion.

Olugboyega (2016) acknowledged the vital role played by BIM in EAC project as it ensures that all aspect of the project was fully captured without omissions. BIM is a significant tool in the enhancing lifecycle and knowledge sharing in the construction project (Olanrewaju et al., 2020). Despite this importance, BIM is yet to be fully implemented in most construction projects as Anifowose et al. (2018) recorded a 40\% level of awareness. The EAC project demonstrated the significant benefits that can be derived from the full implementation of BIM in the Nigerian construction industry. Fig. 1-6 shows some of the BIM models developed for the EAC project.

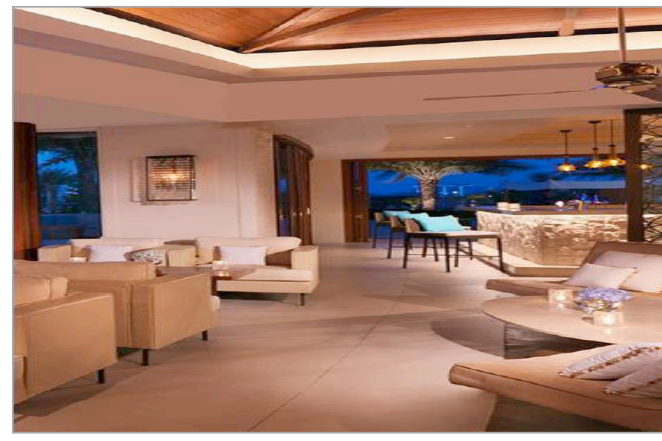

Sources: Eko Brochure (2013); South Energy (2013); Olugboyega (2016).

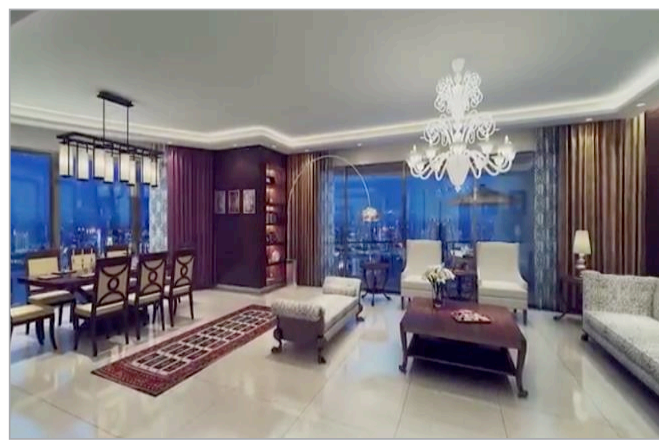

Sources: Eko Brochure (2013); South Energy (2013); Olugboyega (2016).

The research process for this study is divided into four distinctive processes namely; literature survey, questionnaire design and distribution, questionnaire collection and data analysis, and presentation of the result as shown in Fig. 7. A similar approach was adopted in Olanrewaju and Okorie (2019) for dividing research into stages. To achieve the objectives of this study, a literature survey was conducted on BIM uses, BIM and software packages. The quantitative research approach was adopted for this study. Furthermore, the review of relevant literature resulted in the formulation of a structured questionnaire based on 5-point Likert-scale measurement. Collins (2010) maintains that Likert scales are effective to elicit participants' opinions on various statements.

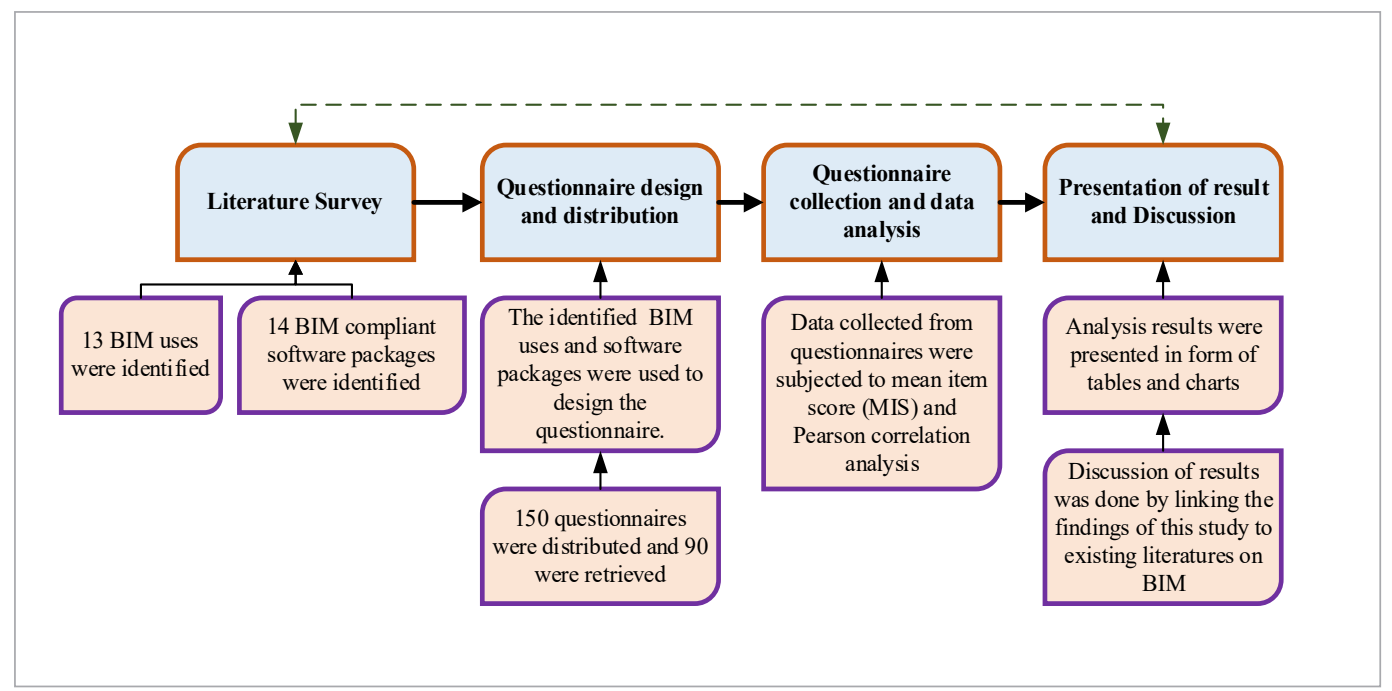

Fig. 7

Research Processes 
Questionnaires were administered to the relevant built environment professionals based in Lagos, the commercial city of Nigeria. The scope of this study was limited to Lagos due to its remarkable growth and demands for infrastructure development. A recent study revealed that the state has received huge investments over the years which includes; Lekki free trade zone, Eko Atlantic city, Dangote petroleum refinery, Island international airport Lekki and deep seaport (Ogunde et al., 2017). Out of one hundred and fifty (150) questionnaires were distributed, ninety (90) were completed and returned, and this resulted in a response rate of $60 \%$. The response rate achieved in this survey provides reasonable data for analysis based on Collins (2010).

IBM SPSS version 23 and Microsoft Excel were used for data analysis. The study adopted a descriptive (Mean Item Score) and inferential (Pearson Correlation) statistics to analyse data obtained from respondents. Mean Item Score (MIS) was used to rank the awareness of analyse BIM uses. The variables were rated against a scale to assist in assessing the significance of each BIM uses. The scale was then transformed into an average otherwise known as mean item score (MIS) for each factor to determine the ranks of the different factors. It is represented mathematically below:

$$
M I S=\frac{5 n_{5}+4 n_{4}+3 n_{3}+2 n_{2}+n_{1}}{\left(n_{5}+n_{4}+n_{3}+n_{2}+n_{1}\right)}
$$

Where; $n_{1}=$ Number of respondent(s) for 'not aware', $n_{2}=$ Number of respondent(s) for 'less aware', $n_{3}=$ Number of respondent(s) for 'neutral', $n_{4}=$ Number of respondent(s) for 'aware' and $n_{5}=$ Number of respondent(s) for 'highly aware. Table 2 shows the decision rule for MIS.

Table 2 Decision Rule for MIS

\begin{tabular}{c|c|c}
\hline Scale & MIS & Decision/Remark \\
\hline 5 & 4.50 to 5.00 & Highly aware \\
\hline 4 & 3.50 to 4.49 & Aware \\
\hline 3 & 2.50 to 3.49 & Neutral \\
\hline 2 & 1.50 to 2.49 & Less aware \\
\hline 1 & 0.00 to 1.49 & Not aware \\
\hline
\end{tabular}

Source: Morenikeji (2006).

$$
r=\frac{N \Sigma x y-(\Sigma x)(\Sigma y)}{\sqrt{\left[N \Sigma x^{2}-(\Sigma x)^{2}\right]\left[N \Sigma y^{2}-(\Sigma y)^{2}\right]}}
$$

Where; $r=$ Pearson correlation, $N=$ number of data, $\sum x y=$ sum of product of $x$ and $y, \sum x=$ sum of $\mathrm{x}, \sum \mathrm{y}=$ sum of $\mathrm{y}, \sum \mathrm{x}^{2}=$ sum of squared $\mathrm{x}$ and $\sum \mathrm{y}^{2}=$ sum of squared $\mathrm{y}$.

\section{Characteristics of Respondents}

The characteristics of the respondents were categorized using the gender, profession, academic qualification, working experience and type of practice. Fig. 8 shows that $80 \%$ were male while $20 \%$ female. Fig. 9 shows the profession of the respondents, $24 \%$ were quantity surveyors having a majority, followed by Builders and Civil Engineers with 20\%, following closely by Architects with $19 \%$ and Estate Surveyors with 17\%.

Fig. 10 shows the academic qualification of the respondents, $1 \%$ of the respondents were Doctorate Degree holders, 40\% had Bachelor's Degree, 34\% Higher National Diploma holders, 22\% were Master's Degree holders, and 3\% were National Diploma holders. Fig. 11 shows the working expe- 
rience of the respondents, $40 \%$ of the respondents have 5-10 years of working experience, $32 \%$ had less than 5 years working experience, $12 \%$ had $11-15$ years, $10 \%$ had $16-20$ years with the lowest being 21 years and above having 6\%.

\section{Awareness Level of BIM Uses in the Nigerian Construction Industry}

Table 3 shows thirteen (13) BIM uses categorized into three stages of building construction (Design Stage, Construction / Building Stage, and Operation / Facility Management Stage). Under Design Stage, seven (7) BIM uses were identified with mean score ranging between 2.800 and 3.322. These BIM uses at design stage ranged from Cost Estimation to Sequencing which is the least ranged. To get the BIM use respondents are very much aware of at the design stage, a mean score threshold of 3.000 was set. As a result, only six (6) BIM uses were above 3.000 and considered significant. These BIM uses are: Cost estimation (Mean $=3.322$; $\mathrm{SD}=1.069 ; t=-1.578 ; \alpha=0.872)$, Construction planning (Mean $=3.311$; SD $=1.056 ; t=-1.697$; $\alpha=0.875$ ), 3D coordination (Mean $=3.144$; SD $=1.250 ; t=-2.698 ; \alpha=0.872)$, Prefabrication (Mean = 3.067; SD = 1.216; $t=-3.381 ; \alpha=0.870$ ), Visualization $($ Mean $=3.044$; SD $=1.090 ; t=$ -3.963; $\alpha=0.877$ ), and Constructability analysis (Mean $=3.022 ; \mathrm{SD}=1.196 ; t=-3.766 ; \alpha=0.868$ ). Under Construction / Building Stage, three (3) BIM uses were identified with a mean score ranging between 2.789 and 3.033. BIM uses at construction/building stage ranged from Construction Monitoring to Fabrication which is the least ranged. To get the BIM use respondents are very much aware of at the construction/building stage, a mean score threshold of 3.000 was also set. As a result, only one (1) BIM use was above 3.000 and considered significant. This BIM use is Construction monitoring (Mean $=3.033$; SD = 1.106; $t=-4.002 ; \alpha=0.872)$.

Under Operation / Facility Management Stage, three (3) BIM uses were identified with a mean score ranging between 2.489 and 2.900 . BIM uses at operation/facility management stage ranged from Asset Management to Record Modelling which is the least ranged. To get the

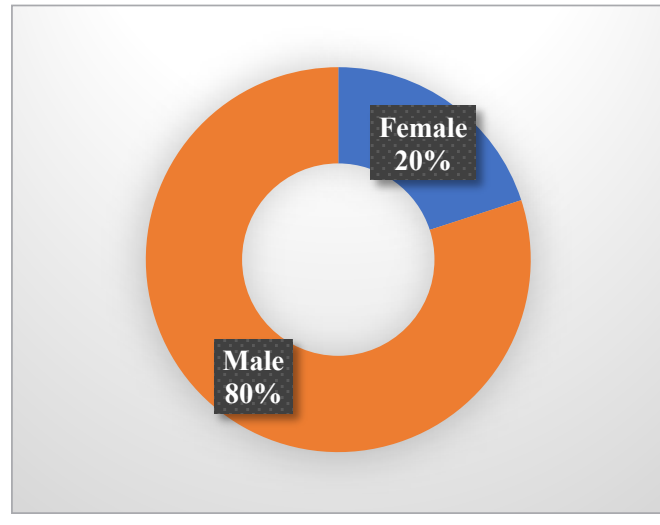

Fig. 8

Gender

Fig. 9

Profession

Fig. 10

Academic Qualification

Fig. 11

Working Experience 
BIM use respondents are very much aware of at the construction/building stage using the same mean threshold previously used, no BIM use at the operation/facility management stage was above 3.000. This indicates that majority of the respondents are not very much aware of the use of $\mathrm{BIM}$ at the operation/facility management stage.

\begin{tabular}{|c|c|c|c|c|c|c|c|c|}
\hline Awareness of BIM & $\mathrm{S} / \mathrm{N}$ & Variables & Mean & SD & t-value & $\alpha$ & $p$-value & $\mathrm{R}$ \\
\hline Uses & \multicolumn{8}{|c|}{ Design Stage } \\
\hline & 1 & Cost estimation & 3.322 & 1.069 & -1.578 & 0.872 & 0.118 & 1 \\
\hline & 2 & Construction planning & 3.311 & 1.056 & -1.697 & 0.875 & 0.093 & 2 \\
\hline & 3 & 3D coordination & 3.144 & 1.250 & -2.698 & 0.872 & 0.008 & 3 \\
\hline & 4 & Prefabrication & 3.067 & 1.216 & -3.381 & 0.870 & 0.001 & 4 \\
\hline & 5 & Visualization & 3.044 & 1.090 & -3.963 & 0.877 & 0.000 & 5 \\
\hline & 6 & Constructability analysis & 3.022 & 1.196 & -3.766 & 0.868 & 0.000 & 6 \\
\hline & 7 & Sequencing & 2.800 & 1.083 & -6.131 & 0.872 & 0.000 & 7 \\
\hline & \multicolumn{8}{|c|}{ Construction / Building Stage } \\
\hline & 8 & Construction monitoring & 3.033 & 1.106 & -4.002 & 0.872 & 0.000 & 1 \\
\hline & 9 & Maintenance scheduling & 2.967 & 0.930 & -5.443 & 0.875 & 0.000 & 2 \\
\hline & 10 & Fabrication & 2.789 & 1.107 & -6.096 & 0.868 & 0.000 & 3 \\
\hline & \multicolumn{8}{|c|}{ Operation / Facility Management Stage } \\
\hline & 11 & Asset management & 2.900 & 1.112 & 24.735 & 0.888 & 0.000 & 1 \\
\hline & 12 & Building system analysis & 2.589 & 1.059 & -8.163 & 0.883 & 0.000 & 2 \\
\hline & 13 & Record modelling & 2.489 & 1.008 & -9.513 & 0.881 & 0.000 & 3 \\
\hline
\end{tabular}

$\mathrm{SD}=$ Standard Deviation; $\mathrm{R}=$ Rank; $\alpha=$ Cronbach's Alpha.

Correlation analysis was used to show the relationship between the awareness levels at different stages of a building as shown in Table 4. The results from the correlation analysis show that there is a strong and significant relationship between the level of awareness at the design stage and construction stage $(r=.647, p<.001)$. There is a weak but significant relationship between the level of awareness at the design stage and operation/facility management stage $(r=.301, p=.004)$. Lastly, it was revealed that there is a fairly strong relationship between construction/building stage and operation/facility management stage $(r=.509, p<.001)$.

Table 4

Correlation Matrix for BIM Awareness at Different Stages of a Building

\begin{tabular}{c|l|c|c|c}
\hline \multicolumn{1}{|c|}{ Stages } & 1 & 2 & 3 \\
\hline 1 & Design Stage & 1 & & \\
\hline 2 & Construction / Building Stage & $.647^{* *}$ & 1 & \\
\hline 3 & Operation / Facility Management Stage & $.301^{* *}$ & $.509^{* *}$ & 1 \\
\hline
\end{tabular}

**. Correlation is significant at the 0.01 level (2-tailed). 
Fig. 12 shows the model for BIM uses awareness at different stages of a building in Nigeria. It is evident that the awareness level is only high at the design stage. This result validated previous researches by Thurairajah and Goucher (2013); Raphael and Priyanka (2014); Wu et al. (2014a); Wu et al. (2014b); and Sunil et al. (2017) where it was stated that most of BIM related developments are in the pre-construction area of cost management.

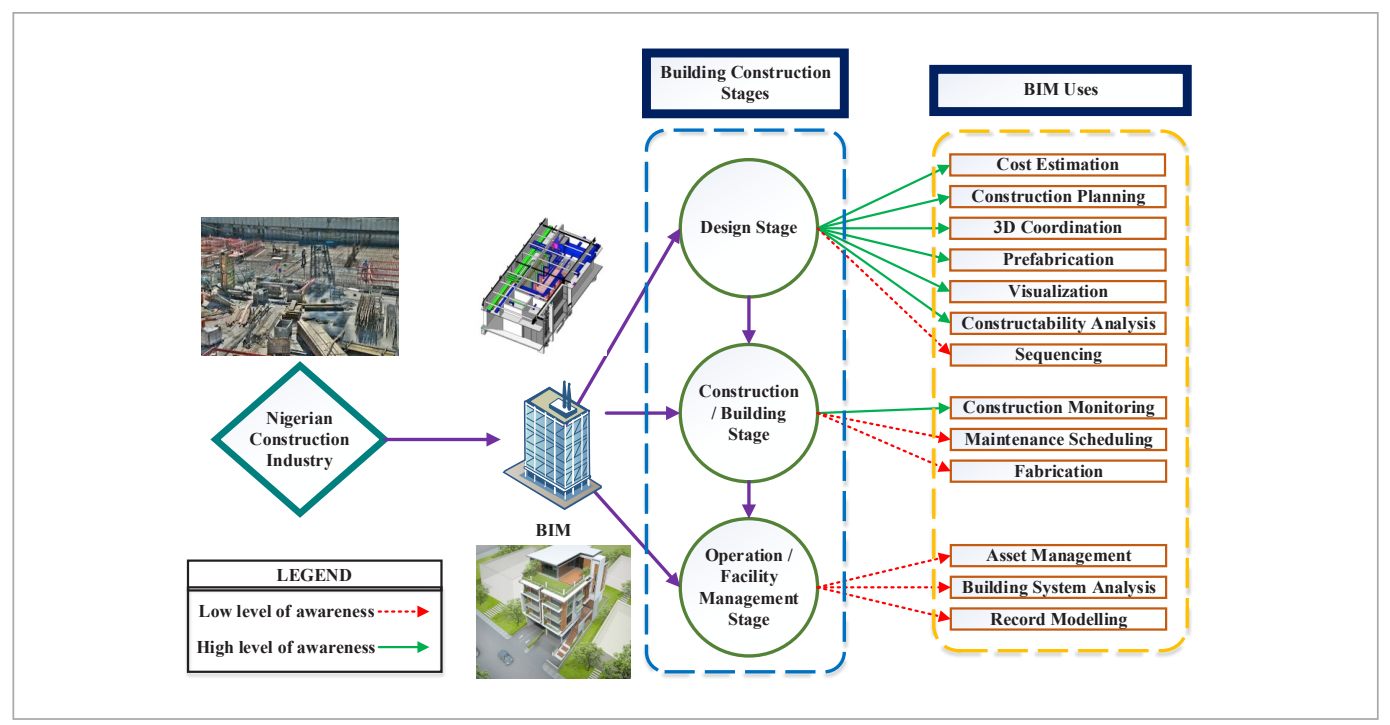

\section{BIM Compliant Software Usage and Awareness in the Nigerian Construction Industry}

Fig. 13 shows the BIM compliant software usage and awareness in the Nigerian construction industry. Fourteen (14) BIM compliant software packages were identified from the literature. 75\% of the respondents were aware of Revit Architecture while $65 \%$ use it, $92 \%$ were of Bentley BIM Suite while $12 \%$ use it, $86 \%$ were aware of Archicad while $36 \%$ use it, $85 \%$ were aware of SketchUp while $59 \%$ use it, $92 \%$ were aware of Navisworks Manage while $56 \%$ use it, $90 \%$ were aware of Autodesk Quantity Takeoff while 69\% use it, and 90\% were aware of QS CAD while 25\% use it. Furthermore, $42 \%$ were aware of Tekla Structures while 17\% use it, 38\% were aware of VICO Software while $9 \%$ use it, $48 \%$ were aware of ArchiFM while 37\% use it, $8 \%$ were aware of Green Building Studio while 2\% use it, 10\% were aware of Digital project while 1\% use it, $69 \%$ were aware of Masterbill while 21\% use it, and 75\% were aware of PowerCivil while 19\% use it. On average, it can be deduced that the majority of the respondents are aware of BIM compliant soft-

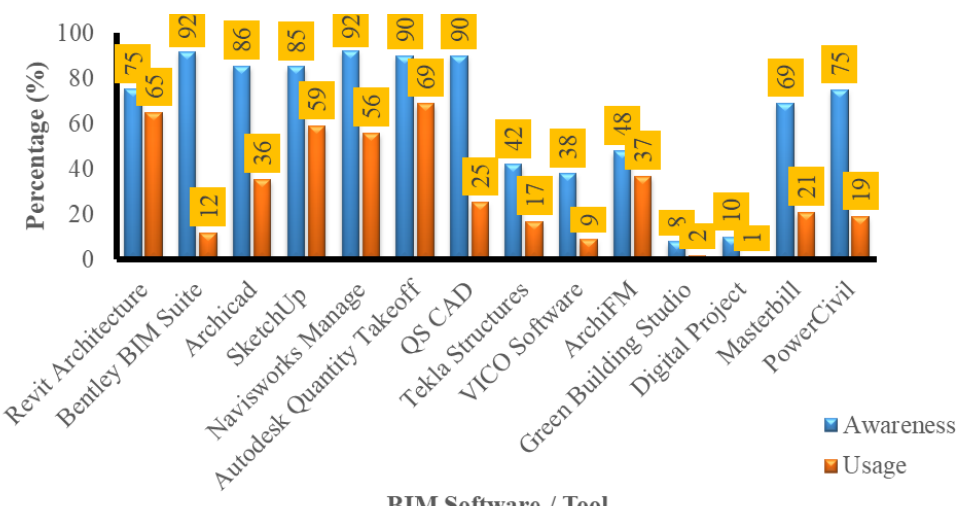

BIM Software / Tool
Fig. 12

Model for Current BIM Uses and Awareness at Different Stages of a Building in Nigeria

Fig. 13

BIM Compliant Software Usage and Awareness 
ware packages but cannot purchase it due to its high cost. Also, the technicalities of BIM compliant software packages and inadequate personnel training has prevented most professionals in the Nigerian construction industry from using BIM compliant software packages. The commonly used software packages were Autodesk Quantity Takeoff, Revit Architecture, and SketchUp. These software packages were also identified in previous researches (Dare-Abelet al., 2014; Ibem and Laryea, 2014; and Al-Matarneh and Fethi, 2017) as CAD tools that allow Architects to develop architectural plans, compile layouts, and design conceptual elements and present complete design drawings on the computer before presentation to the clients (Ibem et al., 2018).

This study has presented the results of a questionnaire survey with the main aim to ascertain the current state of BIM in the Nigerian construction industry. The analysis revealed that BIM is central to the successful management of construction project but most stakeholders in Nigeria are not aware of it uses at the operation/facility management stage of a building. It is also evident from the results that BIM awareness level is only high at the design stage of a building. The study also modelled the current state of BIM in the Nigerian construction industry indicating the evel of awareness of each BIM uses. Most construction professionals are not very much aware of the use of BIM for sequencing, maintenance schedule, fabrication, asset management, building system analysis, and record modelling. Furthermore, this study revealed the commonly used BIM compliant software packages in the Nigerian construction industry to be: Autodesk Quantity Takeoff, Revit Architecture, and SketchUp. The use of BIM-compliant software in the Nigerian construction industry is poor as most built environment professionals such as Architects use it to compile layouts, develop architectural plans, and design conceptual elements.

The study generated several practical implications which may apply to other developing countries. Firstly, it created a road map for Nigerian construction industry stakeholders on the areas of BIM usage. This would be of great benefit as regards policy formulation for BIM and as well make stakeholders aware of the areas that require considerable attention for BIM to be fully implemented in the Nigerian construction industry. Secondly, the output of this research will also be useful to the academicians as it would aid the effective and efficient development of academic syllabus for built environment courses to include the areas of BIM usage with the low level of awareness.

\section{Research Limitations and Future Directions}

Regardless of the findings of this research, it still has some potential shortfalls. The sample size was relatively small and the geographical area covered is small which may affect the generalization of the research. Future research may consider a wide geographical area which can cover all or major States in Nigeria. Another limitation of this study is the number of BIM compliant software and usage considered. A further study may include more BIM compliant software and usage not included in this study.

\section{Recommendation}

The following recommendations were suggested:

_ Stakeholders Education: Stakeholders of the construction industry should be educated on how to use BIM compliant software packages throughout the life cycle of a building and its benefits;

- Openness to New Technologies: Stakeholders of the construction industry should be open to adopting new construction technologies which will increase the productivity of construction works;

Investment in BIM research: Government should invest heavily on BIM-related research to enhance the body of knowledge on BIM in Nigeria and develop a suitable framework for BIM implementation; and

Policy Development: Government should enact policies that will encourage the implementation of BIM in Nigeria. 


\section{Acknowledgement}

This research study was supported by the research funding of Dollahills Research Lab, Dollasoft Technologies. The authors appreciate the reviewers for their valuable comments and suggestions towards improving the initial and subsequent drafts of this paper.

Adelekan, I. (2012). Coastal Cities at Risk. Lagos City Report. Advanced institute in data for coastal cities at risk.

Ajibade, I. (2017). Can a future city enhance urban resilience and sustainability? A political ecology analysis of Eko Atlantic city, Nigeria. International Journal of Disaster Risk Reduction, 26, 85-92. https://doi.org/10.1016/j.ijdrr.2017.09.029

Akdag, S. G., and Maqsood, U. A roadmap for BIM adoption and implementation in developing countries: the Pakistan case. Archnet-IJAR: International Journal of Architectural Research, 2019.

Al-Matarneh, R. and Fethi, I. Assessing the Impact of CAD Design Tool on Architectural Design Education. Malaysian Online Journal of Educational Technology, 5(1), 2017, pp.1-20.

Alufohai, A. J. Adoption of Building Information Modeling and Nigeria's Quest for Project Cost Management. FIG Working Week 2012, Knowing to manage the territory, protect the environment, evaluate the cultural heritage Rome, Italy, 6-10 May 2012.

Anifowose, O. M., Babarinde, S. A. and Olanrewaju, O. I. Adoption Level of Building Information Modelling by Selected Professionals in Kwara State. Environmental Technology and Science Journal, 9(2); 2018, pp. 35 - 44. DOI: https://doi.org/10.13140/ RG.2.2.17530.34247.

Aryani, A. L., Suzila, M., Narimah, K., and Mohamad, S. F. Building Information Modelling (BIM) Application Malaysian Construction Industry. International Journal of Construction Engineering and Management, 2(4A), 2013, pp. 1-6.

Azhar, S., Khalfan, M., and Maqsood, T. Building information modelling (BIM): now and beyond. Australasian Journal of Construction Economics and Building, 12(4), 2012, pp. 15-28. https://doi.org/10.5130/ AJCEB.v12i4.3032

Babarinde, S. A. Assessment of The Adoption Level of Building Information Modelling by Selected Construction Professionals in Kwara-State. Unpublished Bachelor Degree Thesis in Department of Quantity Surveying, Federal University of Technology, Minna. 2017.

BIM Guide. First steps to BIM competence: a guide for specialist contractors. SEC Group/National Specialist Contractors Council BIM working Group, 2013.

BuildingSmart. A strategy for the focused adoption of building information modelling and related digital technologies and processes for the Australian built environment sector. National Building Information Modelling Initiative, Building Smart Australasia, Sydney, Volume 1. 2012.

Channels Television. Building the great wall of Lagos, 2010 [Online]. Available. www.channelstv.com. [2020, March 17].

Channels Television. A special focus on Eko Atlantic City. A lighthouse production for Channels television, 2014. [Online]. Available. www.channelstv.com [2020, March 17].

Collins, H. Creative Research: The Theory and Practice of Research for the Creative Industries, Lausanne: AVA Publishing SA. 2010.

Dare-Abel, O. A., Igwe, J.M. and Ayo, C.K. Proficiency, and Capacity Building of Human Capital in Architectural Firms in Nigeria. International Journal of Architecture and Design, 25(2), 2014, pp.1133-1139.

Eastman, C., Teicholz, P., Sacks, R. and Liston, K. BIM Handbook: A Guide to Building Information Modelling. 2nd ed. John Wiley \& Sons Inc, New Jersey, USA. 2011. Eko Brochure. Eko Pearl Towers. [Online], 2013. Available. www.ekopearl.org [2020, March 17].

Eko Atlantic. Eko Atlantic Nigeria's New Global City, Issue 1. Accessed from: https://www.ekoatlantic. com/milestones/Eko-Atlantic-Milestones-Issue-1. pdf. 2016.

Foster, B. BIM for Facility Management: Design for Maintenance Strategy. Journal of Building Information Modelling, Spring, 2011, pp.18-19.

Froese, M. The impact of emerging information technology on project management for construction. Automation in Construction 19(5), 2010, pp. 531-538. https://doi.org/10.1016/j.autcon.2009.11.004

Gamil, Y. and Rahman, I. A. R. Awareness and challenges of building information modelling (BIM) implementation in the Yemen construction industry. Journal of Engineering, Design and Technology, 17(5); 2019, pp. 1077-1084. https://doi.org/10.1108/JEDT-03-2019-0063

Granholm, L. Finland, Norway, Singapore, USA Lead Progress in Construction, Industry Presentation. BIMsight. 2011.

Grilo, A., and Jardim-Goncalves, R. Value proposition on interoperability of BIM and collaborative working environments. Automation in Construction 19(5), 2010, pp. 522-530. https://doi.org/10.1016/j. autcon.2009.11.003

\section{References}


Ibem, E.O. and Laryea, S. Survey of Digital Technologies in Procurement of Construction Projects. Automation in Construction, 46, 2014, pp. 11-21. https://doi.org/10.1016/j.autcon.2014.07.003

Ibem, E.O., Uwakonye, U.O., Akpoiroro, G.O. Somtochukwu, M., and Oke, C.A. Building Information Modeling (BIM) Adoption in Architectural Firms in Lagos, Nigeria. International Journal of Civil Engineering and Technology (IJCIET), 9(9), 2018, pp. 902-915.

Ibrahim, Y. M. and Abdullahi, M. Introduction to Building Information Modelling. Presented at a 3-day workshop/annual general meeting of the Nigerian Institute of Quantity Surveyors, Port-Harcourt, Nigeria. 2016.

Jensen, P. A., and Johannesson E. I. Building Information Modelling in Denmark and Iceland. Journal of Engineering, Construction and Architectural Management, 20(1), 2014, pp. 99-110. https://doi.org/10.1108/09699981311288709

Jordani, D.A. BIM and FM: The Portal to Lifecycle Facility Management. Journal of Building Information Modelling. 2010.

Kushwaha, V. Contribution of Building Information Modelling (BIM) to solve problems in the Architecture, Engineering and Construction (AEC) Industry and Addressing Barriers to Implementation of BIM. International Journal of Engineering and Technology, 3(1), 2016, pp. 100-105.

Maurico, J.O. Opportunities for Technological Innovations in Current Construction Practices. Unpublished Master's Thesis, Massachusetts Institute of Technology. Cambridge. U.S.A. 2001.

McGraw Hill Construction. Global Industry Trends with Building Information Modeling (BIM). Construction Innovation Forum, 2013.

Meseko, A. A. Opportunities and Risks for Foreign Real Estate Developers in Nigeria. International Journal of Economics, Commerce and Management, 11(7), 2014.

Ogunde, A., Babalola, F., Akinola, G. A., Ogundipe, K. E., Ademola, S. A., Akuete, E. The Utilization of Building Information Modeling in Nigerian Construction Industry: Challenges and Prospects. Proceedings of the 29th International Business Information Management Association Conference in Vienna, Austria. 2017.

Olanrewaju O. I., Chileshe N., Babarinde S. A., Sandanayake, M. Investigating the barriers to building information modeling (BIM) implementation within the Nigerian construction industry. Engineering, Construction and Architectural Management, Vol. ahead-of-print No. ahead-of-print. 2020 May 8. https://doi.org/10.1108/ECAM-01-2020-0042
Olanrewaju, O. I. and Okorie, V.N. Exploring the Qualities of a Good Leader Using Principal Component Analysis. Journal of Engineering, Project, and Production Management, 2019, 9(2), pp. 142-150. http:// www.ppml.url.tw/EPPM_Journal/volumns/09_02 July_2019/ID_220.htm. https://doi.org/10.2478/jeppm-2019-0016

Olanrewaju, O. I., Idiake, J.E., Oyewobi, L.O., and Akanmu, W. P. Global Economic Recession: Causes and Effects on Nigeria Building Construction Industry. Journal of Surveying, Construction and Property, 9(1); 2018, pp. 9-18. https://doi.org/10.22452/jscp.vol9no1.2

Olawumi, T. O. and Chan, D. W. M. Development of a benchmarking model for BIM implementation in developing countries. Benchmarking: An International Journal, 26(4); 2018, pp. 1210-1232. https:// doi.org/10.1108/BIJ-05-2018-0138

Olugboyega, 0. Building Information ModellingBased Projects in Nigeria: Evidences from Eko Atlantic City. PM World Journal, 5(10). 2016.

Oyedeji, B. Sustainable design Strategies for Eko Atlantic City, 2014.

Patacas, J., Dawood, N., and Kassem, M. Evaluation of IFC and COBie as Data Sources for Asset Register Creation and Service Life Planning. 14th International Conference on Construction Applications of Virtual Reality in Construction and Conference on Islamic Architecture. Sharjah, UAE. 16-18, November 2014.

Penttilä, H. Describing the Changes in Architectural Information Technology to Understand Design Complexity and Free-Form Architectural Expression. ITCON11: Special Issue the Effects of CAD on Building Form and Design Quality, 2006, pp. 395-408.

Raphael, V. and Priyanka, J. Role of Building Information Modelling (BIM) in Quantity Surveying Practice. International Journal of Civil Engineering and Technology, 5(12), 2014, pp. 194-200.

Reddy, K.P. BIM for Building Owners and Developers: Making a Business Case for Using BIM on Projects. United States of America. John Wiley and Sons, Inc. 2012. https://doi.org/10.1002/9781119572602

RICS. International BIM Implementation Guide (First ed.). Parliament Square, London. 2014.

Schueter, A. and Thessling, F. Building Information Model based energy/exergy performance assessment in early design stages. Automation in Construction, 18(2), 2008, pp. 153- 163. https://doi. org/10.1016/j.autcon.2008.07.003

South Energy. Eko Atlantic. Eko Atlantic Milestone Issue (1), 2013 [Online]. Available. www.ekoatlantic com [2020, March 17]. 
Sunil, K., Pathirage, C., and Underwood, J. Factors impacting Building Information Modelling (BIM) implementation in cost monitoring and control. 3rd IPGRC 2017 Conference Proceedings. Item available at http:// usir.salford.ac.uk/43978/ (accessed 1/3/2020).

Thurairajah, N. and Goucher, D. Advantages and Challenges of Using BIM: A Cost Consultant's Perspective. Paper presented at the 49th ASC Annual International Conference. 2013.

Usman, J. Assessing the Readiness of the Client Sector to Adopt BIM Technologies in their Project Delivery Process. Bachelor degree thesis, Ahmadu Bello University, Zaria, Nigeria, Nigeria. 2015.

Wong, A., Wong, F. and Nadeem, A Comparative Roles of Major Stakeholders for the Implementation of BIM in Various Countries. Hong Kong Polytechnic University. 2018.
Wu, S., Wood, G., Ginige, K., and Jong, S. W. A technical review of BIM based cost estimating in UK quantity surveying practice, standards and tools. ITcon, 19, 2014a, pp. 534-562.

Wu, S., Wood, G., Ginige, K., and Jong, S. W. How Can BIM support the New Rules of Measurement (NRM1)? London, UK: RICS, 2014b. Retrieved from http://www.rics.org/uk/knowledge/research/researchreports/how-does-bim-support-nrm1/.

Yan, H. and Damian, P., Benefits and Barriers of Building Information Modelling, in Ren, A., Ma, Z. and Lu, $X$. (Eds), Proceedings of the 12th International Conference on Computing in Civil and Building Engineering (ICCCBE XII) \& 2008 International Conference on Information Technology in Construction (INCITE 2008), 16th-18th October 2008, Beijing, China.

\section{OLUDOLAPO IBRAHIM OLANREWAJU}

\section{Senior Researcher}

Dollahills Research Lab, Dollasoft

Technologies

\section{Main research area}

Sustainability, green building, and construction informatics.

\section{Address}

Lagos, Nigeria

Tel. +2347033787668

E-mail:

oludolapoolanrewaju2012@gmail.com

\section{SUNDAY AJIBOYE BABARINDE}

Researcher I

Dollahills Research Lab,

Dollasoft Technologies

Main research area

Risk management.

Address

Lagos, Nigeria

Tel. +2348165176173

E-mail:

spenpe196@gmail.com
COMFORT

SALIHU

Researcher I

Dollahills Research Lab, Dollasoft Technologies

Main research area

Modular construction.

\section{Address}

Lagos, Nigeria

Tel. +2347067547685

E-mail:

salihucomfort@gmail.com

\section{About the Authors}

